\title{
Psychological correlates of parental burnout in hearing mothers of deaf children: personality, satisfaction with life, and posttraumatic growth
}

\author{
Joanna Kobosko ${ }^{1,2}$, Małgorzata Sekułowicz ${ }^{3}$, Lech Śliwa ${ }^{1,2}$, Joanna Rostkowska ${ }^{1,2,4}$, \\ W. Wiktor Jedrzejczak ${ }^{1,2}$, Henryk Skarzynski ${ }^{1,2}$ \\ ${ }^{1}$ Institute of Physiology and Pathology of Hearing, Warsaw, Poland \\ 2 World Hearing Center, Nadarzyn, Poland \\ ${ }^{3}$ Faculty of Physical Education, University School of Physical Education, Wrocław, Poland \\ ${ }^{4}$ Maria Grzegorzewska University, Warsaw, Poland
}

\begin{abstract}
HOW TO CITE:
Kobosko, J., Sekułowicz, M.,

Śliwa, L., Rostkowska, J.,

Jedrzejczak, W.W., Skarzynski, H. (2021). Psychological correlates

of parental burnout in hearing

mothers of deaf children:

personality, satisfaction with life, and posttraumatic growth. International Journal of Special

Education, 36(1), 89-98

CORRESPONDING AUTHOR:

Joanna Kobosko;

j.kobosko@ifps.org.pl

DOI:

https://doi.org/10.52291/

ijse.2021.36.9

COPYRIGHT STATEMENT:

Copyright: (C) 2021 Authors.

Open access publication under the terms and conditions of the Creative Commons Attribution (CC BY) license (http://creativecommons. org/licenses/by/4.0/).
\end{abstract}

\begin{abstract}
A child's disability is a risk factor for its parents experiencing parental burnout $(\mathrm{PB})$. Here we investigate this problem in hearing mothers of deaf and hard of hearing $(\mathrm{DHH})$ children. We look at the psychological dimension of the mothers' personality in terms of the Big Five model, satisfaction with life (SWL), and posttraumatic growth (PTG). The study takes account of the sociodemographics of the mothers and their children and other factors related to the child's deafness and their type of hearing assistance. The study was conducted through letters sent to 559 hearing mothers of which $29 \%$ responded. Responding mothers completed several questionnaires: the Parental Burnout Measure (PBM-12), International Personality Item Pool-Big Five Markers-20 (IPIP-BFM-20), Posttraumatic Growth Inventory (PTGI), and a general questionnaire. A VAS scale was used to assess SWL and satisfaction with the child's rehabilitation.

Results showed that the level of PB the mothers experienced was significantly lower than in mothers of children with non-deafness disabilities. SWL and emotional stability, intellect/imagination, agreeableness, extraversion, and satisfaction with the child's rehabilitation were inversely correlated with $\mathrm{PB}$, but only SWL and emotional stability were significant PB predictors. PTG in the mothers was at an average level and not correlated with PB. Similarly, the sociodemographic characteristics of mother and child and child's deafness -related factors were not correlated with PB. Low levels of emotional stability and SWL are associated with vulnerability of the mothers to PB. Our finding of a lack of relationship between PB and PTG suggest that some mothers of deaf children may experience "illusory PTG", which is related to avoidance -oriented coping strategies including denial coping.
\end{abstract}

Keywords: parental burnout; hearing mothers; deaf children; personality; satisfaction with life; posttraumatic growth 


\section{INTRODUCTION}

Parental burnout (PB) afflicts about 4\% of parents in Poland (Szczygieł et al., 2020). It can be defined as "a state of intense exhaustion related to one's parental role, in which one becomes emotionally detached from one's children and doubtful of one's capacity to be a good parent" (Mikolajczak et al., 2019). This psychological state is an effect of intense, prolonged parental stress that the parent cannot effectively cope with. Usually, it coexists with symptoms of depression and/or anxiety (Lebert-Charron er al., 2018; Roskam et al., 2017; Mikolajczak \& Roskam, 2020; Sánchez-Rodríguez et al., 2019; Sekułowicz, 2013; Szczygieł et al., 2020). In other words, PB is an indicator of difficulty in coping with parenthood, of being a mother (or father) of the child (Bornstein, 2020; Kobosko \& Zalewska, 2011; Kobosko et al., 2021). Mothers are particularly prone to PB (Mikolajczak et al., 2018; Mikolajczak \& Roskam, 2018; Sekułowicz, 2013; Szczygieł et al., 2020). PB inevitably affects the child and the quality of the parent-child relationship, causing increased emotional distance between the parent and the child or escalation of neglectful and perhaps violent behavior towards the child (Mikolajczak et al., 2019; Szczygieł et al., 2020).

PB reflects dysfunction in the family, especially relating to the parental couple (Lebert-Charron et al., 2021; Szczygieł et al., 2020). The type of parenting is also relevant, including parental practices and agreement between the parents about parental decisions (Mikolajczak et al., 2018; Szczygieł et al., 2020). In terms of protection against $\mathrm{PB}$, important factors include psychological functioning of the parents with their attachment style (Mikolajczak et al., 2018), as well as the parents' personality profiles, particularly their emotional stability (Le Vigouroux et al., 2017; Le Vigouroux \& Scola, 2018; Mikolajczak et al., 2018; Sekułowicz et al., 2019; Szczygieł et al., 2020). Other factors conducive to the risk of $\mathrm{PB}$ include the sociodemographics of the parents and the child, notably the sex of the parent (female), having a child younger than 5 , being a single mother, and having a part-time job (Lebert-Charron et al., 2019; Mikolajczak et al., 2018; Szczygieł et al., 2020). Other characteristics of the child, such as having a disability or severe disease, are also significant, giving increased risk of $\mathrm{PB}$ (Lindström et al., 2010, 2011; Mikolajczak et al., 2018; Sekułowicz, 2013; Sekułowicz et al., 2019; Szczygieł et al., 2020). Notwithstanding, a Finnish study (Sorkkila, 2018) showed that sociodemographic factors explain only about $8 \%$ of $\mathrm{PB}$ variance.

\section{Disability of the child and PB}

Parents who have a child with special needs that interfere with family life tend to more often experience PB. The degree of PB may also depend on the type and severity of the child's development disorder (Olsen et al., 2014; Sekułowicz, 2013). Venkatesan and Varghese (2013) have found that a higher degree of hearing loss is associated with a higher level of PB in mothers. Similarly, among caregivers of children with autism spectrum disorder (ASD), a feeling of being burdened has been shown to correlate with higher levels of the child's disability (Cetinbakis et al., 2020). Concerning types of disability, the highest level of $\mathrm{PB}$ is found in parents of children with ASD compared to parents of children with any other type of disability (Kwiatkowski \& Sekułowicz, 2017; Sekułowicz, 2013; Venkatesan \& Varghese, 2013). At the same time, Çengelci (2009) did not find any difference in PB between mothers of children with ASD and those with Down syndrome. The level of PB may be higher if the child is a boy (Sekułowicz, 2013), but the age of the parent or the age of the child do not correlate with PB (Ahmadi et al., 2021; Kwiatkowski \& Sekułowicz, 2017). Higher PB has been found in incomplete families (Sekułowicz, 2013), although some studies have shown the opposite (Ahmadi et al., 2021; Kwiatkowski \& Sekułowicz, 2017). Lower education level of the parent of a child with a disability or severe chronic condition is related to increased risk of PB (Ahmadi et al., 2021; Çengelci, 2009; Cetinbakis et al., 2020; Sekułowicz, 2013).

\section{Personality and PB}

Different personality traits of parents are related to PB: a lower risk of $\mathrm{PB}$ is correlated with higher self-efficacy, emotional intelligence, resiliency, and sense of coherence, regardless of the child's developmental disorder (Kwiatkowski \& Sekułowicz, 2017; Sekułowicz, 2013; Szczygiel et al., 2020). Studies performed using the Big Five Model show a positive relationship between $\mathrm{PB}$ and neuroticism, and a negative one between $\mathrm{PB}$ and agreeableness and conscientiousness (Le Vigouroux et al., 2017). In the Polish population, higher extraversion, but not conscientiousness, relates to lower levels of PB (Szczygieł et al., 2020).

\section{Satisfaction with life and PB}

Satisfaction with life (SWL) in parents with PB is reduced (Szczygieł et al., 2020), in the same way as parents of children with a disability (Aktan et al., 2020; Cetinbakis et al., 2020; Sekułowicz, 2013), including mothers of deaf children before the child has received a cochlear implant (Yiğit et al., 2018). It has been shown that PB is less likely if the 
mother of a child with a disability has higher SWL (Aktan et al., 2021; Çalışkan et al., 2021; Sekułowicz, 2013).

\section{Posttraumatic growth and PB}

Parents of children with disabilities often experience posttraumatic growth (PTG) following what is a highly stressful and sometimes traumatic life event - diagnosis of a disability in their child. PTG means "a positive psychological change experienced as a result of the struggle with highly challenging life circumstances" (Tedeschi \& Calhaun, 2004). In such parents, PTG has an average level of intensity regardless of the type of impairment (Byra et al., 2017, 2021; Cetinbakis et al., 2020; Kobosko, 2016; Laufer \& Isman, 2021). Among hearing parents of deaf children, $41.9 \%$ have obtained a high level of positive change and $32.4 \%$ a medium level. In mothers of deaf children, the level of PTG was higher than in fathers (Kobosko, 2016). Considering that there is an inverse correlation between burnout and PTG found in such groups as pediatric nurses (Hamama-Raz et al., 2020), a similar relationship between PB and PTG may be expected in mothers of children with disabilities.

\section{THE CURRENT STUDY}

This study of the psychological determinants of PB in hearing mothers of deaf children poses the question about the relationship between $\mathrm{PB}$ and certain other measurable factors: the Big Five personality traits, SWL, PTG, as well as sociodemographic factors concerning the mothers (age, marital/partnership status, education, having one or more children), their children (sex, age), and other factors related to the child's deafness (degree of hearing loss, number of cochlear implants, additional disability, mother's satisfaction with the child's rehabilitation, and mother's satisfaction with the decision about cochlear implantation).

\section{METHODS}

\section{Study participants and procedure}

The study involved 162 hearing mothers of deaf and hard-of-hearing (DHH) children (51.25\% were boys) aged between 7 months and 17 years (mean 85.35 months). The children were diagnosed with hearing loss (severe or profound) according to BIAP; the mean age at diagnosis was 11 months. Among the 162 children, 144 (88.8\%) were users of one or two cochlear implants (CIs), with
Table 1. Sociodemographic characteristics of mothers and their DHH children, and data on the children's deafness and hearing amplifying devices

\begin{tabular}{|c|c|}
\hline \multicolumn{2}{|l|}{ Mothers of DHH children $(n=162)$} \\
\hline $\begin{array}{l}\text { Age (years) - M (SD) } \\
\text { (min-max) }\end{array}$ & $\begin{array}{c}36.93(5.87) \\
23-57\end{array}$ \\
\hline $\begin{array}{l}\text { Marital/partnership status } \\
\text { In a relationship }-\mathrm{n}(\%) \\
\text { Single }-\mathrm{n}(\%)\end{array}$ & $\begin{array}{c}147(90.7) \\
15(9.3)\end{array}$ \\
\hline $\begin{array}{l}\text { Education } \\
\text { Lower (secondary or post-secondary } \\
\text { non-tertiary) }-\mathrm{n}(\%) \\
\text { Tertiary - } \mathrm{n}(\%) \\
\text { Missing data - } \mathrm{n}(\%)\end{array}$ & $\begin{array}{l}62(38.3) \\
99(61.1) \\
1(0.6)\end{array}$ \\
\hline $\begin{array}{l}\text { Number of children } \\
\text { One child }-\mathrm{n}(\%) \\
\text { More than one child - } \mathrm{n}(\%)\end{array}$ & $\begin{array}{c}50(30.9) \\
112(69.1)\end{array}$ \\
\hline \multicolumn{2}{|l|}{ DHH children $(n=162)$} \\
\hline $\begin{array}{l}\text { Sex } \\
\text { Boys - n (\%) } \\
\text { Girls - n (\%) }\end{array}$ & $\begin{array}{l}83(51.2) \\
79(48.8)\end{array}$ \\
\hline $\begin{array}{l}\text { Age (months) - M (SD) } \\
\text { (min-max) }\end{array}$ & $\begin{array}{c}85.35(40.6) \\
7-204\end{array}$ \\
\hline $\begin{array}{l}\text { Age } \\
\text { Young children }(<5 \text { years old })-\mathrm{n}(\%) \\
\text { Older children ( } 5 \text { years old and over) }-\mathrm{n}(\%)\end{array}$ & $\begin{array}{c}49(30.25) \\
113(69.75)\end{array}$ \\
\hline $\begin{array}{l}\text { Age at deafness confirmation (months) - M (SD) } \\
\text { (min-max) } \\
\text { Missing data (n) }\end{array}$ & $\begin{array}{c}11.14(15.61) \\
0.1-94 \\
2\end{array}$ \\
\hline $\begin{array}{l}\text { Degree of hearing loss } \\
\text { Severe }-\mathrm{n}(\%) \\
\text { Profound }-\mathrm{n}(\%)\end{array}$ & $\begin{array}{c}39(24.1) \\
123(75.9)\end{array}$ \\
\hline $\begin{array}{l}\text { Additional disability } \\
\text { Present }-\mathrm{n}(\%) \\
\text { None }-\mathrm{n}(\%)\end{array}$ & $\begin{array}{c}29(17.9) \\
133(82.1)\end{array}$ \\
\hline $\begin{array}{l}\text { Age when fitted with a HA (months) - M (SD) } \\
\text { (min-max) } \\
\text { Missing data (n) }\end{array}$ & $\begin{array}{c}15.81(18.75) \\
1-132 \\
7\end{array}$ \\
\hline $\begin{array}{l}\text { Type of amplification } \\
\text { One } \mathrm{Cl}-\mathrm{n}(\%) \\
\text { Two Cls - } \mathrm{n}(\%) \\
\text { Hearing aids - } \mathrm{n}(\%)\end{array}$ & $\begin{array}{l}87(53.7) \\
57(35.2) \\
18(11.1)\end{array}$ \\
\hline $\begin{array}{l}\text { Age at first } \mathrm{Cl} \text { (months) - M (SD) } \\
\text { (min-max) } \\
\text { Missing data (n) }\end{array}$ & $\begin{array}{c}30.37(25.38) \\
6-177 \\
3\end{array}$ \\
\hline $\begin{array}{l}\text { Age at second } \mathrm{Cl} \text { (months) - M (SD) } \\
\text { (min-max) } \\
\text { Missing data (n) }\end{array}$ & $\begin{array}{l}55.49(30.0) \\
18-192 \\
4\end{array}$ \\
\hline
\end{tabular}

bilaterally implanted children comprising $32.7 \%$ of all implanted children. Age at first cochlear implantation was, on average, 30.3 months. DHH children raised in incomplete families comprised $9.3 \%$ of the group. Detailed sociodemographic information about mothers and their DHH children, their deafness, and CI-related information are presented in Table 1 . 
This study was conducted via mail in the years 2017-19. It is based on mothers of DHH children who were patients of the Institute of Physiology and Pathology of Hearing in Warsaw, Poland. Mothers received a pack of questionnaires with a cover letter inviting their anonymous participation in a research study. The response rate was $29 \%$. The Institute's Bioethics Committee approved the project.

Statistical calculations were done using Statistica v. 12 (StatSoft Inc., Tulsa, OK, USA). The following tests were used: t-test, Mann-Whitney U-test, Pearson correlation coefficient, and multiple linear regression (for assessing which variables were predictors for $\mathrm{PB}$ ). A $95 \%$ confidence level $(\mathrm{p}<0.05)$ was chosen as the criterion of significance.

\section{MEASURES}

Parental Burnout Inventory (PBI-12), developed by Sekułowicz and Kwiatkowski (2013), is a Polish tool for assessing PB. It is a version of the Maslach Burnout Inventory (MBI) for assessing job burnout, adapted for parents of children with disabilities. It comprises 12 items on a 4-point Likert-type scale, with responses from 4 (very often) to 1 (never). Factor analysis singled out two key scales on PBI-12: exhaustion (E) and helplessness $(\mathrm{H})$, containing six items in each scale. The authors recommend using just one factor, the total of all the items, and it ranges from 12 to 48 points. The higher the score, the more severe the $\mathrm{PB}$. In a study on mothers of children with disabilities, Cronbach's alpha for PBI-12 was 0.90 (Sekułowicz et al., 2019).

Polish adaptation of the Short IPIP-BFM-20 (Topolewska et al., 2014) was used to assess the mothers' personality dimensions. This questionnaire is an abbreviated version of Goldberg's Big Five Markers from the International Personality Item Pool (IPIP-BFM-50) (Goldberg, 1990). It includes five scales, 4 items in each, assessing extraversion, agreeableness, conscientiousness, emotional stability, and intellect/imagination. Responses are scored on a five-point Likert-type scale from 1 (strongly disagree) to 5 (strongly agree). A higher score means a higher intensity of a particular personality dimension.

Posttraumatic Growth Inventory (PTGI) by Tedeschi and Calhoun (1996) in Polish adaptation (Juczyński \& Ogińska-Bulik, 2010) is a tool that can be used to assess positive changes that people go through because of traumatic experiences (such as in our study the diagnosis of deafness in the child) - for example 'I more clearly see that I can count on people in times of trouble'. PTGI comprises 21 items that in Polish adaptation are divided into 4 scales: changes in perception of oneself, relationships with others, greater appreciation for life, and spiritual changes. Responses are scored from 0 (I did not experience this change as a result of my crisis) to 5 (I experienced this change to a very great degree as a result of my crisis). The overall score is a total of responses ranging from 0 to 105 points. The higher the overall score, the higher the posttraumatic growth the person went through. Cronbach's alpha in our study was 0.95.

The information survey included questions related to sociodemographic data about the child (sex, age) and the mother (age, marital/partnership status, education, number of children), information related to the child's deafness (child's age at the time of diagnosis, degree of hearing loss, child's age when provided with a hearing aid (HA) and CI, number of CIs, and child's age at the first and second cochlear implantation and experience with one and two CIs). The survey also included items for assessing the mothers' satisfaction with life, with their DHH child's rehabilitation, and with the $\mathrm{CI}$ or CIs provided. These three kinds of „satisfaction” were scored on a scale from 1 (I am very dissatisfied) to 10 (I am very satisfied).

\section{RESULTS}

\section{Descriptive statistics}

For the mothers of DHH children, descriptive statistics for the analyzed variables - parental burnout (PBM-12), personality dimensions (IPIP-BFM-20), posttraumatic growth (PTGI), satisfaction with life (VAS), satisfaction with rehabilitation (VAS), and satisfaction with CI (VAS) - are presented in Table 2.

In the whole group of mothers of DHH children, the global level of parental burnout (PBM-12) was significantly lower than in mothers of children with disabilities other than deafness reported in other studies, as shown in Table 2.

Using global parental burnout (PBM-12) findings, intergroup comparisons were made based on the following categorical variables. These were variables describing the mothers - education (lower/tertiary), marital/ partnership status (in a relationship/single), number of children (one child/more than one child) - and variab- 
les describing their DHH children [(sex and age $(<5$ years $/ \geq 5$ years)] and those related to deafness [degree of hearing loss (severe/ profound), additional impairments (yes/no), being a CI user (yes/no), number of CIs (one/ two CIs)]. A Mann-Whitney U-test was used with a correction because the dependent variable (parental burnout) was not continuous. Overall parental burnout was found to be similar in all groups. An exception involved mothers where the DHH children had two CIs, in which case it was lower $(\mathrm{M}=22.1$; $\mathrm{SD}=7.29)$ than in children with one $\mathrm{CI}$ $(\mathrm{M}=24.57 ; \mathrm{SD}=7.64)$, and here the trend was statistically significant $(U=1677.0 ; p=0.05)$.

All personality dimensions were found to be lower in mothers of $\mathrm{DHH}$ children than in the general population (Bojanowska \& Urbańska, 2021). Their satisfaction with rehabilitation was on a similar level as in another study of mothers of small DHH children (Kobosko et al., 2021), and their satisfaction with the CI was similar to that recorded in an earlier study of parents of DHH children who used a CI (Kobosko, 2011) (Table 2). However, there is no existing data on SWL measured with a VAS scale in mothers of DHH children.

Global posttraumatic growth (PTGI) in mothers of $\mathrm{DHH}$ children was in the range of average results according to standards for people experiencing various kinds of trauma, including parents confronting their child's disability or a severe disease (Juczyński \& Ogińska-Bulik, 2010).

\section{Correlations}

Table 3 shows Pearson's correlation coefficient between $\mathrm{PB}$ global score and the individual variables describing mothers of $\mathrm{DHH}$ children, including personality dimensions (extraversion, agreeableness, conscientiousness, emotional stability, and intellect/ imagination based on IPIP-BFM-20), posttraumatic growth, satisfaction with life, rehabilitation, and CI (measured with VAS). We found a statistically significant negative correlation between PB global score and 4 of the personality dimensions - the strongest, al-
Table 2. Descriptive statistics for the variables: parental burnout (PBM-12), personality dimensions (IPIP-BFM-20), posttraumatic growth (PTGI), satisfaction with life (VAS), satisfaction with rehabilitation (VAS), and satisfaction with $\mathrm{CI}$ (VAS) in mothers of DHH children.

\begin{tabular}{|c|c|c|c|}
\hline Variable/Measure & $\mathbf{N}$ & $\begin{array}{c}\text { M (SD) } \\
\text { (min-max) }\end{array}$ & Standards \\
\hline Parental burnout (PBM-12) & & & Mothers $(n=246)^{1}$ \\
\hline $\begin{array}{l}\text { Exhaustion (E) } \\
\text { (range 6-24) }\end{array}$ & 162 & $\begin{array}{c}11.85(4.04)^{\star \star *} \\
(6-23)\end{array}$ & $13.9(4.49)$ \\
\hline $\begin{array}{l}\text { Helplessness }(\mathrm{H}) \\
\text { (range 6-24) }\end{array}$ & 162 & $\begin{array}{c}11.65(3.83)^{* * *} \\
(6-23)\end{array}$ & $13.63(3.8)$ \\
\hline $\begin{array}{l}\text { Total (sum) } \\
\text { (range 12-48) }\end{array}$ & 162 & $\begin{array}{c}23.53(7.46)^{\star \star \star} \\
(12-45) \\
\end{array}$ & $27.53(7.68)$ \\
\hline $\begin{array}{l}\text { Personality dimensions } \\
\text { (IPIP-BFM-20) }\end{array}$ & & & $\begin{array}{l}\text { General population } \\
\qquad(\mathrm{n}=1161)^{2}\end{array}$ \\
\hline $\begin{array}{l}\text { Extraversion } \\
\text { (range 4-20) }\end{array}$ & 160 & $\begin{array}{c}11.07(3.49)^{\star \star} \\
(4-18)\end{array}$ & $12(3.36)$ \\
\hline $\begin{array}{l}\text { Agreeableness } \\
\text { (range 4-20) }\end{array}$ & 162 & $\begin{array}{c}13,85(2.65)^{* *} \\
(4-18)\end{array}$ & $14.6(2.62)$ \\
\hline $\begin{array}{l}\text { Conscientiousness } \\
\text { (range 4-20) }\end{array}$ & 162 & $\begin{array}{c}13,38(2.87)^{* * *} \\
(6-18)\end{array}$ & $14.3(2.82)$ \\
\hline & 160 & & $11.5(2.99)$ \\
\hline $\begin{array}{l}\text { Intellect/Imagination } \\
\text { (range 4-20) }\end{array}$ & 161 & $\begin{array}{c}12.22(2.75)^{* \star *} \\
(4-18)\end{array}$ & $14(2.66)$ \\
\hline Posttraumatic growth (PTGI) & & & Women $(n=368)^{3}$ \\
\hline $\begin{array}{l}\text { Changes in perception } \\
\text { of oneself } \\
\text { (range } 0-45 \text { ) }\end{array}$ & 159 & $\begin{array}{c}29.17(9.53)^{* *} \\
(3-45)\end{array}$ & $26.18(9.54)$ \\
\hline $\begin{array}{l}\text { Relationships with others } \\
\text { (range 0-35) }\end{array}$ & 155 & $\begin{array}{r}22.01(8.58) \\
(0-35)\end{array}$ & $22.11(7.65)$ \\
\hline $\begin{array}{l}\text { Greater appreciation for life } \\
\text { (range 0-15) }\end{array}$ & 156 & $\begin{array}{r}11.12(3.45)^{*} \\
(0-15)\end{array}$ & $10.38(3.56)$ \\
\hline $\begin{array}{l}\text { Spiritual changes } \\
\text { (range 0-10) }\end{array}$ & 157 & $\begin{array}{cc}4.99 & (3.09) \\
& (0-10)\end{array}$ & $5.27(2.81)$ \\
\hline $\begin{array}{l}\text { Total } \\
\text { (range 0-105) }\end{array}$ & 150 & $\begin{array}{c}67.49(22.27) \# \\
(7-105) \\
\end{array}$ & $63.95(19.84)$ \\
\hline $\begin{array}{l}\text { Satisfaction with life (VAS) } \\
\text { (range 1-10) }\end{array}$ & 159 & $\begin{array}{r}7.97(1.76) \\
(1-10) \\
\end{array}$ & - \\
\hline $\begin{array}{l}\text { Satisfaction } \\
\text { with rehabilitation (VAS) } \\
\text { (range 1-10) }\end{array}$ & 151 & $\begin{array}{r}8.18(1.78) \\
(1-10)\end{array}$ & $\begin{array}{l}\text { Parents of DHH } \\
\text { children }(\mathrm{n}=64)^{4} \\
\quad 8.22(1.69)\end{array}$ \\
\hline $\begin{array}{l}\text { Satisfaction with CI (VAS) } \\
\text { (range 1-10) }\end{array}$ & 143 & $\begin{array}{r}9.61(1.17) \\
(1-10)\end{array}$ & $\begin{array}{l}\text { Parents of DHH } \\
\text { children }(\mathrm{n}=93)^{5} \\
\quad 9.55(1.27)\end{array}$ \\
\hline
\end{tabular}

Standards are listed in the last column:

for PBM-12 standards are from ${ }^{1}$ Sekułowicz et al., 2019; for IPIP-BFM-20 from ²Bojanowska \& Urbańska, 2021; for PTGl from 3Juczyński \& Ogińska-Bulik, 2010; for Satisfaction with rehabilitation (VAS) from ${ }^{4}$ Kobosko et al., 2021; and for Satisfaction with Cl (VAS) from ${ }^{5}$ Kobosko, 2011 
Table 3. Correlation coefficients between parental burnout (PBM-12) and personality dimensions (IPIP-BFM-20), satisfaction with life, rehabilitation and CIs (VAS), and posttraumatic growth (PTGI) of mothers of DHH children.

\begin{tabular}{l|c}
\hline Variable & $\begin{array}{c}\text { Parental burnout } \\
\text { of mothers of DHH } \\
\text { children (PBM-12) }\end{array}$ \\
\hline Personality dimensions (IPIP-BFM-20) & $-0.26^{\star}$ \\
Extraversion & $-0.23^{\star}$ \\
Agreeableness & -0.1 \\
Conscientiousness & $-0.56^{\star}$ \\
Emotional stability & $-0.35^{\star}$ \\
Intellect/Imagination & $-0.55^{\star}$ \\
\hline Satisfaction with life (VAS) & -0.15 \\
\hline Posttraumatic growth (PTGI) & $-0.19^{\star}$ \\
\hline Satisfaction with rehabilitation (VAS) & -0.01 \\
\hline Satisfaction with Cl (VAS) & \\
\hline
\end{tabular}

* Significant at $p<0.05$

though only moderate, with emotional stability, and the weakest with agreeableness and extraversion. A similar correlation was found between PB and emotional stability, and between $\mathrm{PB}$ and the mothers' satisfaction with life. However, there was no correlation between PB and posttraumatic growth.

\section{Regression analysis}

Regression analysis was performed between $\mathrm{PB}$ and the variables that significantly correlated with $\mathrm{PB}$. The obtained regression model was found to be statistically significant (multiple $\mathrm{R}^{2}=0.429, \mathrm{~F}=15.294 ; \mathrm{p}<0.001$ ). The predictors included in the analysis explained about $40 \%$ of the variability of the dependent variable. Results are presented in Table 4. Only two predictors introduced to the model were found to be significant: the mothers' emotional stability and SWL. The interpretation is that mothers of DHH children who were emotionally stable and satisfied with life had a lower risk of PB.

\section{DISCUSSION}

This study addresses the issue of the parental burnout (PB) of hearing mothers of $\mathrm{DHH}$ children and the mothers' psychological conditions such as personality, satisfaction with life (SWL), and posttraumatic growth (PTG) related to their child's deafness. The study also takes into consideration the mothers' sociodemographic data, their satisfaction with the child's rehabilitation, and their satisfaction with the CI if the child was a CI user. Children's characteristics addressed in the study included sociodemographic and deafness-related factors. So far, there are no published studies on this subject concerning hearing mothers of $\mathrm{DHH}$ children.

$\mathrm{PB}$ in mothers of $\mathrm{DHH}$ children was found to be significantly lower than in mothers whose children had disabilities other than deafness, which have been reported in other Polish studies using the same tool, PBM-12 (Kwiatkowski \& Sekułowicz, 2017; Sekułowicz, 2013; Sekułowicz et al., 2019). Possibly, this reduced PB relates to the fact that mothers of $\mathrm{DHH}$ children largely had a psychological type of burnout, while mothers of children with ASD had strong physical burnout (Varghese \& Venkatesan, 2013). This indicates that mothers of DHH children can more effectively cope with stress, notably parental stress, than can mothers of children having other disabilities (Pisula \& Barańczuk, 2020).

A clear majority of $\mathrm{DHH}$ children from the study group (88\%) used one or two CIs, which means they had undergone cochlear implantation, a highly effective medical intervention that is presently standard procedure in

Table 4. Regression model of predictors of parental burnout (PBM-12) of mothers of DHH children.

\begin{tabular}{l|c|c|c|c|c|c}
\hline & Beta & SE Beta & B & SE B & t & p \\
\hline Satisfaction with life & -0.3534 & 0.0861 & -1.4196 & 0.3457 & -4.1065 & $<0.001^{*}$ \\
\hline Extraversion & -0.0478 & 0.0843 & -0.0974 & 0.1716 & -0.5676 & 0.571 \\
\hline Agreeableness & -0.0221 & 0.0755 & -0.0671 & 0.2285 & -0.2934 & 0.770 \\
\hline Emotional stability & -0.3543 & 0.0777 & -0.9066 & 0.1990 & -4.5564 & $<0.001^{*}$ \\
\hline Intellect/Imagination & -0.1038 & 0.0854 & -0.2752 & 0.2265 & -1.2152 & 0.227 \\
\hline Satisfaction with rehabilitation & 0.0149 & 0.0788 & 0.0600 & 0.3172 & 0.1892 & 0.850 \\
\hline
\end{tabular}

Dependent variable: parental burnout; * Significant difference 
Poland (Skarżyński et al., 2018). No doubt implantation helped improve the child's functioning, particularly in the areas of speech, language, and communication development (Quittner et al., 2016; Sharma et al., 2020); it probably also helped the psychological functioning of their parents (Kobosko et al., 2014; Yiğit, et al., 2018). However, our data on PB intensity cannot be compared to the general population of parents of typically developing children, as there are no studies on this subject using PBM-12.

No significant relationship was found between PB and the sociodemographic data of the mothers and DHH children included in this study. Similarly, PB did not correlate with any additional impairments in $\mathrm{DHH}$ children. This lack of correlation is similar to findings concerning mothers of children having impairments other than deafness (Sekułowicz, 2013; Kwiatkowski \& Sekułowicz, 2017) - although some of these factors are significant in the general population, for example, the child's age (Mikolajczak et al., 2018; Szczygieł et al., 2020). The degree of the child's hearing loss was also irrelevant to $\mathrm{PB}$, although the number of CIs was significant at the level of a statistical trend - mothers of DHH children who had two CIs were less likely to suffer from PB.

We found that lower PB was correlated with higher maternal satisfaction with their child's hearing and speech rehabilitation; in other words, mothers who can see progress in their child's rehabilitation are less burnt out (or not burnt out at all). Earlier studies reported a statistically significant relationship between satisfaction of mothers with rehabilitation and developmental outcomes of their DHH children (Kobosko et al., 2021). This relationship can involve a feedback effect, so that mothers who function better psychologically in turn create better conditions for their children's development. For example, mothers who are more emotionally attuned to their children create an environment where their children develop a better sense of self (Kobosko \& Zalewska, 2011; Stern, 1995; Zalewska, 1998).

Satisfaction with life is a component of well-being, and in mothers of $\mathrm{DHH}$ children, the level is similar to that of the general Polish population (Janoś-Kresło, 2017). SWL is a significant predictor and a protective factor for $\mathrm{PB}$, as it also is in mothers of children with other disabilities (Sekułowicz, 2013). In mothers of autistic children, SWL is also a protective factor for relieving the burden of caregiving (Cetinbakis et al., 2020).
Mothers who are more satisfied with life are less depressed and anxious (Gigantesco et al., 2021) and, as the results of this study show, also less inclined to be burnt out. This finding corresponds with the results of other studies using PBM-12 (Sekułowicz, 2013) or other tools (Aktan et al., 2021; Çalışkan et al., 2021; Szczygieł et al., 2020). Previous studies show that SWL also correlates with social support and dyadic adjustment of the parents (Centinbakis et al., 2020). Thus, the results of the present study give an indication of how best to target parental support interventions (MacKenzie \& Eack, 2021): the focus should be on psychological counseling, psychotherapy of the marital relationship (Kobosko, 2013; Szczygieł et al., 2020; Zalewska, 1998), and the mother's ability to create and maintain a support system (Stern, 1995). All these factors are conducive to improved satisfaction with life and reduce the risk of PB.

Regarding the Big Five personality traits, mothers of DHH children score lower on all studied traits than do the general population, indirectly indicating a lower level of well-being (Bojanowska \& Urbańska, 2021). Almost all the personality traits of mothers of $\mathrm{DHH}$ children are important, to various degrees, for coping with the risk of PB. Emotional stability and intellect/imagination are the strongest negative factors for PB risk, less so for extraversion and agreeableness. These results are somewhat different to those obtained in a study of the general Polish population, which showed that the protective personality traits for PB are higher levels of extraversion and agreeableness, and lower levels of neuroticism (Szczygieł et al., 2020). In a study on the general population of Spanish parents, the factor most strongly correlated with $\mathrm{PB}$ was, significantly and negatively, conscientiousness (Le Vigouroux et al., 2017), not extraversion as in this study. In the light of these results, it is possible to conclude that, for mothers of DHH children, intellect/ imagination (interpreted as openness to experience) is a specific personality trait that is protective for $\mathrm{PB}$. Thus, those mothers of $\mathrm{DHH}$ children who are cognitively active, open to experience, creative, imaginative, and have wide-ranging interests are less prone to suffer from $\mathrm{PB}$ (Goldberg, 1990).

However, among the Big Five, only emotional stability is a significant and predictive factor for $\mathrm{PB}$ in mothers of DHH children. That trait is related to excitability and emotional balance, emotional resilience, and tolerance to frustration; it is inversely correlated with depression and anxiety (Rodríguez-Ramos et al., 2021). 
Posttraumatic growth of mothers of DHH children was at an average level (Juczyński \& Ogińska-Bulik, 2010), indicating that in response to their child's deafness, they experienced positive changes at an average level, similar to mothers of children with other disabilities or severe health conditions (Ahmadi et al., 2021; Byra et al., 2017, 2021; Laufer \& Isman, 2021). In this context, it was surprising to find no relationship between PB and PTG. In mothers of DHH children, PTG was not a preventive factor for $\mathrm{PB}$, as it is in pediatric nurses (Hamama-Raz et al., 2020). A possible explanation for this result is the two-component (Janus-faced) model of PTG in which two sides of that phenomenon are distinguished: a real, constructive PTG and an illusory PTG, which operate in tandem (Zoellner \& Maercker, 2006). We think it is likely that in some mothers of DHH children, illusory PTG prevails, and this is related to avoidance-coping strategies such as denial, which in the longer term are harmful to well-being and health (Livneh, 2016) and, hence detrimental to coping with $P B$. The relationship between PTG and PB requires further study, including clinical psychological interviews, in groups of mothers having children with various disabilities and conditions.

\section{CONCLUSIONS}

In mothers of DHH children, SWL and the Big Five model personality traits play an essential role in $\mathrm{PB}$, especially emotional stability and SWL, which were fo- und to be predictive of PB. The psychological well-being of the mothers, in terms of avoiding $\mathrm{PB}$, is also correlated with their satisfaction with progress in the hearing and speech rehabilitation of their $\mathrm{DHH}$ children and, as a statistical trend, with the fact whether their child has a bilateral cochlear implant. No relationship was found between PB and PTG.

Offers of help to mothers of DHH children should include various forms of psychological intervention to bolster their emotional stability - such as psychoeducation, psychological counseling, and psychotherapy. At the same time, mothers of DHH children should receive support to boost SWL and their DHH children's rehabilitation. Together, these factors are likely to be effective in countering parental burnout.

\section{ACKNOWLEDGEMENT}

We thank Andrew Bell and Olga Wanatowska for comments on an earlier version of this article.

DISCLOSURE STATEMENT

No potential conflict of interest

was reported by the authors.

FUNDING: None. 


\section{REFERENCES}

Ahmadi, B., Sabery, M., \& Adib-Hajbaghery, M. (2021). Burnout in the primary caregivers of children with chronic conditions and its related factors. Journal of Client-Centered Nursing Care, 7(2), 139-148. https://doi.org/10.32598/JCCNC.7.2.360.1

Aktan, O., Orakcı, Ş., \& Durnalı, M. (2020). Investigation of the relationship between burnout, life satisfaction and quality of life in parents of children with disabilities. European Journal of Special Needs Education, 35(5), 679-695. https://doi.org/10.1080/08856257.2020.1748429

Bojanowska, A., \& Urbańska, B. (2021). Individual values and well-being: The moderating role of personality traits. International Journal of Psychology, 56(5), 698-709. https://doi.org/10.1002/ijop.12751

Bornstein, M. H. (2020). Parental burnout: The state of the science. New Directions for Child and Adolescent Development, 2020(174),169-184. https://doi.org/10.1002/cad.20388

Byra, S., Zubrzycka, R., \& Wójtowicz, P. (2021). Positive orientation and posttraumatic growth in mothers of children with cystic fibrosis - Mediating role of coping strategies. Journal of Pediatric Nursing, 5 , e1-e8. https://doi.org/10.1016/j.pedn.2020.09.009

Byra, S., Żyta, A., \& Ćwirynkało, K. (2017). Posttraumatic growth in mothers of children with disabilities. Hrvaatska Revija Za Rehabilitaijsja Isrrazivanja, 52, 15-27.

Çallşkan, Z., Evgin, D., Caner, N., Kaplan, B., \& Özyurt, G. (2021). Determination of burnout, life satisfaction, and stress coping styles of parents with disabled children. Perspectives in Psychiatric Care, 57(3), 1505-1514. https://doi.org/10.1111/ppc.12746

Çengelci, B. (2009). A comparison of level of anxiety, hopelessness and burnout syndrome of mothers who have children with diagnosis of autism or Down syndrome. Ege Eğitim Dergisi, 10(2), 1-22.

Cetinbakis, G., Bastug, G., \& Ozel-Kizil, E. T. (2020). Factors contributing to higher caregiving burden in Turkish mothers of children with autism spectrum disorders. International Journal of Developmental Disabilities, 66(1), 46-53. https://doi.org/10.1080/20473869.2018.1478630

Gigantesco, A., Fagnani, C., Toccaceli, V., Stazi, M. A., Lucidi, F., Violani, C., \& Picardi, A. (2019). The relationship between satisfaction with life and depression symptoms by gender. Frontiers in Psychiatry, 10, 419. https://doi.org/10.3389/fpsyt.2019.00419.

Goldberg, L. R. (1990). An alternative description of personality: The big-five factor structure. Journal of Personality and Social Psychology, 59(6), 1216-1229. https://doi.org/10.1037//0022-3514.59.6.1216

Hamama-Raz, Y., Hamama, L., Pat-Horenczyk, R., Stokar, Y. N., Zilberstein, T., \& Bron-Harlev, E. (2021). Posttraumatic growth and burnout in pediatric nurses: The mediating role of secondary traumatization and the moderating role of meaning in work. Stress \& Health, 37(3), 442-452. https://doi.org/10.1002/smi.3007

Janoś-Kresło, M. (2017). Jakość życia w świetle wyników badań empirycznych. In K.Błoński, A. Burlita, \& J. Witek (Eds.), Pomiar jakości życia na poziomie lokalnym (na przykładzie powiatu wałeckiego) (pp. 31-44). Wydawnictwo Naukowe Uniwersytetu Szczecińskiego.

Kobosko, J. (2011). Parenting a deaf child. How hearing parents cope with the stress of having deaf children. Journal of Hearing Science, 1(3), 38-42.

Kobosko, J. (2013). Depresja matek i ojców a głuchota dziecka. Znaczenie satysfakcji małżeńskiej jako predyktora nasilenia doświadczanych przez rodziców objawów depresji. Roczniki Pedagogiczne, 5(3), 123-140.

Kobosko, J. (2016). Głuchota dziecka z perspektywy potraumatycznego wzrostu słyszących rodziców. In E. Domagała-Zyśk, A. Borowicz, \& R. Kołodziejczyk (Eds.), Język i wychowanie. Księga jubileuszowa z okazji 45-lecia pracy naukowej Profesor Kazimiery Krakowiak. Wydawnictwo KUL.

Kobosko, J., Ganc, M., Paluch, P., Jędrzejczak, W. W., Fludra, M., \& Skarżyński, H. (2021). Developmental outcomes of young deaf children and the self-perceived parental role of their hearing mothers. International Journal of Pediatric Otorhinolaryngology, 141, 110517. https://doi.org/10.1016/j.jporl.2020.110517

Kobosko, J., Geremek-Samsonowicz, A., \& Skarżyński, H. (2014). Mental health problems of mothers and fathers of the deaf children with cochlear implants. Otolaryngologia Polska, 68(3), 135-142. https://doi.org/10.1016/j.otpol.2013.05.005

Kobosko, J., \& Zalewska, M. (2011). Maternal identity of hearing mothers of deaf adolescents. Empirical studies-An interpersonal approach. The Volta Review, 111(1), 39-59. https://doi.org/10.17955/tvr.111.1.655

Kwiatkowski, P., \& Sekułowicz, M. (2017). Examining the relationship of individual resources and burnout in mothers of children with disabilities. International Journal of Special Education, 32(4), 823-841.

Laufer, A., \& Isman, E. (2021). Posttraumatic growth (PTG) among parents of children with special needs. Journal of Loss and Trauma, O(0), 1-20. https://doi.org/10.1080/15325024.2021.1878336

Le Vigouroux, S. L., \& Scola, C. (2018). Differences in parental burnout: Influence of demographic factors and personality of parents and children. Frontiers in Psychology, 9, 887. https://doi.org/10.3389/fpsyg.2018.00887

Le Vigouroux, S. L., Scola, C., Raes, M.-E., Mikolajczak, M., \& Roskam, I. (2017). The Big Five personality traits and parental burnout: Protective and risk factors. Personality and Individual Differences, 119, 216-219. https://doi.org/10.1016/j.paid.2017.07.023

Lebert-Charron, A., Dorard, G., Boujut, E., \& Wendland, J. (2018). Maternal burnout syndrome: Contextual and psychological associated factors. Frontiers in Psychology, 9, 885. https://doi.org/10.3389/fpsyg.2018.00885

Lindström, C., Åman, J., \& Norberg, A. L. (2010). Increased prevalence of burnout symptoms in parents of chronically ill children. Acta Paediatrica, 99(3), 427-432. https://doi.org/10.1111/j.1651-2227.2009.01586.x

Lindström, C., Aman, J., \& Norberg, A. L. (2011). Parental burnout in relation to sociodemographic, psychosocial and personality factors as well as disease duration and glycaemic control in children with type 1 diabetes mellitus. Acta Paediatrica, 100(7), 1011-1017. https://doi.org/10.1111/j.1651-2227.2011.02198.x

Livneh, H (2016) Denial in medical conditions: A synopsis of its components. Annals of Psychiatry and Mental Health, 4(7): 1084

MacKenzie, K. T., \& Eack, S. M. (2021). Interventions to improve outcomes for parents of children with autism spectrum disorder: A meta-analysis. Journal of Autism and Developmental Disorders, 1-25. https://doi.org/10.1007/s10803-021-05164-9.

Mikolajczak, M., Gross, J. J., \& Roskam, I. (2019). Parental burnout: What is it, and why does it matter? Clinical Psychological Science, 7(6), 1319-1329. https://doi.org/10.1177/2167702619858430

Mikolajczak, M., Raes, M.-E., Avalosse, H., \& Roskam, I. (2018). Exhausted parents: Sociodemographic, child-related, parent-related, parenting and family-functioning correlates of parental burnout. Journal of Child and Family Studies, 27(2), 602-614. https://doi.org/10.1007/s10826-017-0892-4

Mikolajczak, M., \& Roskam, I. (2018). A theoretical and clinical framework for parental burnout: The balance between risks and resources (BR2). Frontiers in Psychology, 9, 886. https://doi.org/10.3389/fpsyg.2018.00886

Mikolajczak, M., \& Roskam, I. (2020). Parental burnout: Moving the focus from children to parents. New Directions for Child and Adolescent Development, 2020(174), 7-13. https://doi.org/10.1002/cad.20376 
Ogińska-Bulik, N., \& Juczyński, Z. (2010). Posttraumatic growth - Characteristic and measurement. Psychiatria, 7(4), 129-142.

Olsen, R. S., Allred, D. W., Mandleco, B., Freeborn, D., \& Dyches, T. (2014). Caregiver burden and sibling relationships in families raising children with Disabilities and typically developing children. Families, Systems \& Health: Journal of Collaborative Family Health Care, 32(2), 241-2 https://doi.org/10.1037/fsh0000047

Pisula, E., \& Barańczuk, U. (2020). Psychometric properties of a Polish version of the parental stress index III (PSI III). Journal of Developmental and Physical Disabilities, 32(3), 455-475. https://doi.org/10.1007/s10882-019-09697-x

Quittner, A., Cejas, I., Bernard, J., \& Niparko, J. (2016). Benefits on cochlear implantation on the whole child: longitudinal changes in cognition, behavior, parenting and health-related quality of life. In N. M. Young, \& K. ller Kirk (Eds.). Pediatric cochlear implantation. (pp. 199-210). Springer Science+Business Media LLC.

Rodríguez-Ramos, Á., Moriana, J. A., García-Torres, F., \& Ruiz-Rubio, M. (2021). Emotional stability is related to 2D: 4D and social desirability in women: Possible implications on subjective well-being and psychopathology. Plos One, 16(3), e0248368. https://doi.org/10.1371/journal.pone.0248368

Sánchez-Rodríguez, R., Orsini, É., Laflaquière, E., Callahan, S., \& Séjourné, N. (2019). Depression, anxiety, and guilt in mothers with burnout of preschool and school-aged children: Insight from a cluster analysis. Journal of Affective Disorders, 259, 244-250. https://doi.org/10.1016/j.jad.2019.08.031

Sekułowicz, M. (2013). Wypalanie się sił rodziców dzieci z niepełnosprawnością. Wydawnictwo Naukowe Dolnośląskiej Szkoły Wyższej.

Sekułowicz, M., Boroń-Krupińska, K., Kwiatkowski, P., \& Latawiec, B. M. (2019). Sense of coherence, resilience and coping as correlates of burnout of parents of children with disabilities: The new burnout screening instrument. Niepełnosprawność. Dyskursy Pedagogiki Specjalnej, 36, 254-268.

Sekułowicz, M., \& Kwiatkowski, P. (2013). The burnout syndrome in parents of children with disabilities; construction of a new research tool. Studia Edukacyjne, 25, 29-50.

Sharma, S. D., Cushing, S. L., Papsin, B. C., \& Gordon, K. A. (2020). Hearing and speech benefits of cochlear implantation in children: A review of the literature. International Journal of Pediatric Otorhinolaryngology, 133, 109984. https://doi.org/10.1016/j.ijporl.2020.109984.

Skarżyński, H., Mielnik-Niedzielska, G., Kochanek, K., Niedzielski, A., Skarżyński, P. H., \& Lorens, A. (2018). Standardy jakości stosowania implantów ślimakowych u niemowląt, dzieci i młodzieży. Nowa Audiofonologia, 7(1) , 7-15, https://doi. org/10.17431/1002947.

Stern, D. N. (1995). The motherhood constellation: A unified view of parent - infant psychotherapy. Basic Books.

Sorkkila, M., \& Aunola, K. (2020). Risk factors for parental burnout among Finnish parents: The role of socially prescribed perfectionism. Journal of Child and Family Studies, 29(3), 648-659. https://doi.org/10.1007/s10826-019-01607-1

Szczygieł, D., Sekulowicz, M., Kwiatkowski, P., Roskam, I., \& Mikolajczak, M. (2020). Validation of the Polish version of the Parental Burnout Assessment (PBA). New Directions for Child and Adolescent Development, 2020(174), 137-158. https://doi.org/10.1002/cad.20385

Tedeschi, R. G., \& Calhoun, L. G. (1996). The Posttraumatic Growth Inventory: Measuring the positive legacy of trauma. Journal of Traumatic Stress, 9(3), 455-472. https://doi.org/10.1002/jts.2490090305

Tedeschi, R. G., \& Calhoun, L. G. (2004). Posttraumatic growth: Conceptual foundations and empirical evidence. Psychological Inquiry, 15(1), 1-18. https://doi.org/10.1207/s15327965pli1501_01

Topolewska, E., Skimina, E., Strus, W., Cieciuch, J., \& Rowiński, T. (2017). The short IPIP-BFM-20 questionnaire. Annals of Psychology, 17(2), 367-384.

Venkatesan, S., \& Varghese, R. (2013). A comparative study of maternal burnout in autism and hearing impairment. International Journal of Psychology and Psychiatry, 1, 101-108. https://doi.org/10.5958/j.2320-6233.1.2.016

Yiğit, E., Edizer, D. T., Durna, Y. M., Altay, M. A., \& Yiğit, Ö. (2018). Satisfaction with life among mothers of pediatric cochlear implant candidates: The impact of implant operation and sociodemographic factors. Journal of International Advanced Otology, 14(2), $202-207$. https://doi.org/10.5152/iao.2018.5531

Zalewska, M. (1998). Dziecko w autoportrecie z zamalowaną twarzą. Psychiczne mechanizmy zaburzeń rozwoju tożsamości dziecka głuchego i dziecka z opóźnionym rozwojem mowy. Jacek Santorski \& CO Wydawnictwo.

Zoellner, T., \& Maercker, A. (2006). Posttraumatic growth in clinical psychology -A critical review and introduction of a two component model. Clinical Psychology Review, 26(5), 626-653. https://doi.org/10.1016/j.cpr.2006.01.008 